\title{
Antibacterial activity of leaves, flowers, and fruits extract of Etlingera elatior from Nagan Raya District, Indonesia against Escherichia coli and Staphylococcus aureus
}

\author{
ERNILASARI ${ }^{1}$, KAMALLIANSYAH WALIL ${ }^{1}$, FITMAWATI $^{2}$, DEWI INDRIYANI ROSLIM ${ }^{2}$, ZUMAIDAR $^{3}$, \\ SAUDAH $^{1, \vee}$, RAYHANNISA $^{4}$ \\ ${ }^{1}$ Faculty of Teacher Training and Education, Universitas Serambi Mekkah. Jl. Unmuha, Batoh, Banda Aceh 23245, Aceh, Indonesia. \\ Tel./fax.: +62-651-26160, `email: saudah@serambimekkah.ac.id, danayulisma@gmail.com \\ ${ }^{2}$ Department of Biology, Faculty of Mathematics and Natural Sciences, Universitas Riau. Kampus Bina Widya, Jl. H.R. Subrantas Km. 12,5, Simpang \\ Baru, Tampan, Pekanbaru 28293, Riau, Indonesia \\ ${ }^{3}$ Department of Biology, Faculty of Mathematics and Natural Sciences, Universitas Syiah Kuala. Jl. Tgk. Syech Abdul Rauf No. 3, Darussalam, Banda \\ Aceh 23111, Aceh, Indonesia \\ ${ }^{4}$ Mathematics and Applied Science Graduate Program, Universitas Syiah Kuala. Jl. Tgk. Syech Abdul Rauf No. 3, Darussalam, Banda Aceh 23111, \\ Aceh, Indonesia \\ ${ }^{5}$ Biology Graduate Program, Faculty of Mathematics and Natural Sciences, Universitas Syiah Kuala. Jl. Tgk Chik Pante Kulu No. 5, Kopelma \\ Darussalam, Syiah Kuala, Banda Aceh 23111, Aceh, Indonesia
}

Manuscript received: 6 August 2021. Revision accepted: 26 September 2021

\begin{abstract}
Ernilasari, Walil K, Fitmawati, Roslim DI, Zumaidar, Saudah, Rayhannisa. 2021. Antibacterial activity of leaves, flowers, and fruits extract of Etlingera elatior from Nagan Raya District, Indonesia against Escherichia coli and Staphylococcus aureus. Biodiversitas 22: 4457-4464. Etlingera elatior is a medicinal plant that has been used by people in Indonesia, especially Acehnese people. Based on its secondary metabolites, E. elatior can be used as antibacterial agents against Gram-positive and Gram-negative. However, to determine the antibacterial activity of E. elatior, the parts of E. elatior that have been used are leaves, flowers, and fruits. This study was aimed to determine the best concentration of ethanol extract of leaves, flowers, and fruits of E. elatior as an inhibitor against Escherichia coli and Staphylococcus aureus. The extract was made by the maceration method with $70 \%$ ethanol as a solvent. Antibacterial activity test was carried out by the diffusion agar method using concentrations of $0.5 \%, 1 \%, 1.5 \%$ and $2 \%$. The results showed that the fruit extract of E. elatior has antibacterial activity with an effective inhibitory zone at a concentration of $2 \%$ is $8.4 \mathrm{~mm}$ (E. coli) and $2.4 \mathrm{~mm}$ (S. aureus). Meanwhile, antibacterial activity of the extract of leaves and flowers against E. elatior cannot determine yet. Identification of leaves, flowers and fruits extract of E. elatior using GC-MS (gas chromatography-mass spectroscopy) showed 56 compounds were detected.
\end{abstract}

Keywords: Antibacterial test, Escherichia coli, Etlingera elatior, Staphylococcus aureus, Suak Bugis

\section{INTRODUCTION}

Indonesia is one of the countries which is rich in biodiversity, including medicinal plants that have been used in healthcare, protect health and disease prevention since time immemorial (Schroeder 2011; Sofowora et al. 2013). Indonesia is the second-highest number of indigenous medicinal plants, after the Amazon rain forest (Elfahmi et al. 2014). Hence, there is a high potential for pharmaceutical and biotechnological research opportunities. Recently, using traditional medicine as an alternative treatment has increased significantly (World Health Organization 2004). Traditional medicines have no side effects, are more affordable than most conventional medicines, as well as availability and compatibility as plant-derived drugs (Fatima and Nayeem 2016; Juwita et al. 2018). Etlingera elatior (Jack) R. M. Sm.) is one type of plant in Indonesia that is widely used as traditional medicine by local people (Silalahi 2016).

E. elatior Jack. RM is a species of plant belongs to Zingiberaceae. E. elatior which has various local names, i.e., Kecombrang in Java, Kincung in North Sumatera, Honje in West Java, Sikala in Southeast Sulawesi, Bongkot in Bali, etc (Poulsen 2012; Sabilu et al. 2017; Oktavia et al. 2019). Meanwhile, in Aceh, these species are known as Bak Kala and Bungong Kala. E. elatior is a medicinal plant that has been used by people in Indonesia, especially Acehnese people. Empirically, E. elatior is used as traditional medicine by the Gayo tribe, Central Aceh District for the treatment of various diseases such as coughs, bloating, fatigue and fatigue syndrome, abdominal pain, as well as postpartum medicine (Saudah et al. 2021).

According to (Jackie et al. 2011; Maimulyanti et al. 2015), E. elatior contains secondary metabolites such as flavonoids, saponins, phenols, terpenoids, tannins, glycosides, steroids, which have bioactivities. This bioactive compound has been reported to exhibit antimicrobial, antidiabetic, anticancer, antioxidant, antiaging, as well as anti-inflammatory (Habsah et al. 2005; Lachumy et al. 2010; Zan et al. 2011; Srey et al. 2014; Ghasemzadeh et al. 2015; Nor Asiah et al. 2019). Previous studies reported that $E$. elatior leaves from aqueous extract can inhibit the 
growth of Escherichia coli and Staphylococcus aureus (Ningtyas 2010). Inline to (Sukandar et al. 2011), the aqueous extract of E. elatior leaves has antibacterial activity against $E$. coli $(10 \mathrm{~mm} / 100 \%)$ and $S$. aureus $(8.663$ $\mathrm{mm} / 20 \%)$. In addition, Sukandar (2010) also revealed that the aqueous extract of E. elatior flower has antibacterial activity against $E$. coli $(4.8 \mathrm{~mm} / 60 \%)$ and $S$. aureus $(6.87$ $\mathrm{mm} / 20 \%$ ).

Phenolic and flavonoids had been reported to have antimicrobial activity through the mechanism of action of bacterial cell-wall destruction (Manoi 2009; Mahboubi et al. 2016). The mechanism of action of saponin as an antibacterial is it can cause leakage of proteins and enzymes of the cell (Madduluri et al. 2013). Saponins including glycosides and aglycone portions, while aglycone portion is steroid and triterpenoid (Manoi 2009). Saponins are divided into three major groups as a triterpenoid, steroid or steroidal glycoalkaloid (Mert-Türk 2005) Another secondary metabolite is tannin, where tannin has ability to pass through the bacterial cell wall up to the internal membrane and inhibit the reverse transcriptase enzyme and DNA topoisomerase so that bacterial cells cannot be formed (Dabbaghi et al. 2009).

Escherichia coli is a gram-negative bacteria or also known as E. coli. E. coli is commonly found in the lower intestine of humans and animals and causes acute diarrheal diseases in all age groups (Bettelheim 2000). To detect the presence of bacteria in surface water, E. coli is commonly used as indicator of fecal contamination. Meanwhile, Staphylococcus aureus is gram-positive aerobic organism that causes skin infections, necrosis, abscess formation, sometimes pneumonia, osteomyelitis and endocarditis (Jawetz 2005; Bush and Vazquez-Pertejo 2021). S. aureus is resistant to several antibiotics, including the lactamase, methicillin, nafcillin, oxacillin and vancomycin groups (Jawetz et al. 2008). Resistance is a global problem that often arises in the treatment of infectious diseases. The increase in bacterial resistance to antibiotics provides a great opportunity to obtain antibacterial compounds by utilizing bioactive compounds from the diversity of plants in Indonesia (Nuria et al. 2009).

Based on the description of E. elatior as medicinal plant and its potential as antibacterial agent against $E$. coli and $S$. aureus. Therefore, the aim of this study is to determine the best concentration of ethanol extracts of leaves, flowers and fruits of E. elatior to inhibit the growth of E. coli and $S$. aureus together with identification of its chemical profiles by GC-MS analysis.

\section{MATERIALS AND METHODS}

\section{Study area}

The research was conducted in Suak Bugis, Nagan Raya District, Aceh, Indonesia (Figure 1). The experiment was conducted at the Regional Health Laboratory, Jakarta and Laboratory of Microbiology, Department of Biology, Faculty of Mathematics and Natural Sciences, Syiah Kuala University, Banda Aceh, Indonesia, from October to December 2020.

\section{Procedures}

\section{Sample collection}

The research was used purposive sampling method. Samples of E. elatior were collected from seven different areas of Suak Bugis, Nagan Raya District, Aceh including leaves, flowers and fruits. The leaves, flowers and fruits were taken randomly from each stem. The sample was identified by Saida Rasnovi from Herbarium of the Department of Biology, Syiah Kuala University as E. elatior. The coordinate of each location is presented in Table 1.
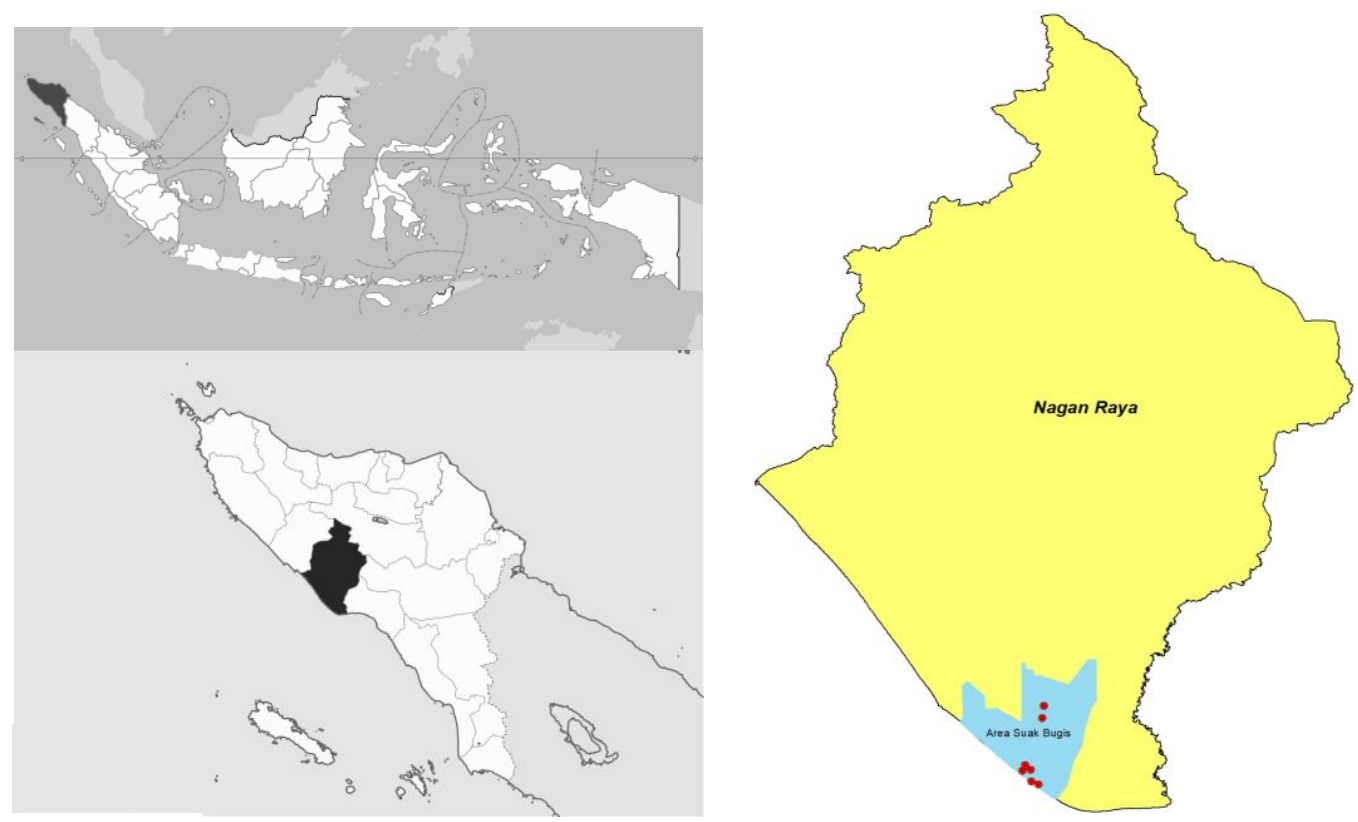

Figure 1. The collection sites of Etlingera elatior in Suak Bugis, Nagan Raya District, Aceh, Indonesia 
Table 1. The coordinates of the Etlingera elatior sampling area

\begin{tabular}{|c|c|c|c|c|c|}
\hline Species & Sample type & Sampling area & Sampling year & The coordinates & Information \\
\hline E. elatior & Leaves, flowers, fruit & Suak Bugis & 2020 & 96.49311"; 3.850495" & Point 1 (T1) \\
\hline E. elatior & Leaves, flowers, fruit & Suak Bugis & 2020 & 96.491415"; 3.836671" & Point 2 (T2) \\
\hline E. elatior & Leaves, flowers, fruit & Suak Bugis & 2020 & $96.473506 " ; 3.7832 "$ & Point 3 (T3) \\
\hline E. elatior & Leaves, flowers, fruit & Suak Bugis & 2020 & 96.479313"; 3.777966" & Point 4 (T4) \\
\hline E. elatior & Leaves, flowers, fruit & Suak Bugis & 2020 & 96.470503”; 3.776872" & Point 5 (T5) \\
\hline E. elatior & Leaves, flowers, fruit & Suak Bugis & 2020 & 96.47989"; 3.764773" & Point 6 (T6) \\
\hline E. elatior & Leaves, flowers, fruit & Suak Bugis & 2020 & 96.487234"; $3.761149 "$ & Point 7 (T7) \\
\hline
\end{tabular}

\section{Sample preparation}

Leaves, flowers, and fruit were harvested and washed by distilled water then cut into small pieces. Then air-dried samples in the open space. After drying process, samples were stored at $20^{\circ} \mathrm{C}$ and pulverized into powders.

\section{Extraction}

The extract was obtained by the maceration method with $70 \%$ ethanol as a solvent. The extraction process begins with making simplicial from leaves, flowers, and fruits that have been pulverized. The simplicial powder of about 100 grams was inserted into container, then add solvent until all ingredients were submerged and left for 24 hours. While stirring every 1 x 24 hours, after 24 hours the mixture was filtered using Whatman filter paper in a filter funnel. The filtrate was stored and the residue was soaked in a new solvent for 24 hours and repeated until the solvent was colorless. The filtrate obtained was then separated by a vacuum rotary evaporator at $50^{\circ} \mathrm{C}$ to separate the solvent from the thick extract filtrate of leaves, fruits, and flowers. The filtrate was stored in bottles at $20^{\circ} \mathrm{C}$ for further analysis.

\section{Phytochemical screening}

Phytochemical tests were performed on leaves, flowers and fruit extract of E. elatior to determine the content of flavonoids, saponins, tannins, alkaloids, triterpenoids, and steroids qualitatively.

\section{Alkaloid testing}

A total of $3 \mathrm{~mL}$ of each sample extract was added by the reagents of Mayer, Dragendorff, and Wagner. The positive result of Mayer reagent was confirmed by white precipitate, red precipitate (Dragendorff) and brown precipitate (Wagner).

\section{Phenolic testing}

A total of $3 \mathrm{~mL}$ of extract was put into a test tube, then one drop of $1 \% \mathrm{FeCl}_{3}$ solution was added to $3 \mathrm{~mL}$ of the extract solution. A positive result of phenolic was indicated by the formation of a yellow, orange or red color.

\section{Flavonoid testing}

A total of $3 \mathrm{~mL}$ of sample extract was put into a test tube, then added 0.1 gram of magnesium powder, $1 \mathrm{~mL}$ of concentrated $\mathrm{HCl}$ and $1 \mathrm{~mL}$ of amyl alcohol. The mixture was shaken vigorously and allowed the layers to separate. The presence of flavonoids is indicated by the formation of red in the amyl alcohol layer.

\section{Saponin testing}

A total of $3 \mathrm{~mL}$ of sample extract was put into a test tube, then shaken vigorously and left for 10 minutes. The presence of saponin is indicated by the formation of stable foam.

\section{Tanin testing}

A total of $3 \mathrm{~mL}$ of sample extract was put into a test tube, then add 3 drops of $1 \% \mathrm{FeCl}_{3}$. The formation of blue or greenish-black color indicates the presence of tannins compounds.

\section{Steroids and triterpenoids testing}

A total of $3 \mathrm{~mL}$ of sample extract was dissolved in hot ethanol, heated for 5 minutes, then the solution was filtered. The filtrate result was dried by heating, then $1 \mathrm{~mL}$ of diethyl ether was added. A total of 3 drops of the ether fraction were transferred to a drip plate, then add 3 drops of acetic anhydride and 1 drop of concentrated sulfuric acid. Formation of reddish or violet color indicates the presence of triterpenoids, whereas the formation of green or blue color indicates the presence of steroids.

\section{Gas Chromatography-Mass Spectroscopy (GC-MS) test}

The analytical method using Gas ChromatographyMass Spectroscopy (GC-MS) can measure the type and content of compounds in a sample both qualitatively and quantitatively. Leaves, flowers and fruits extract of $E$. elatior were analyzed using GC-MS Agilent 19091S-436 HP-5MS. $1 \mu \mathrm{L}$ of the extract was injected into GC-MS which was operated using a glass column length of $25 \mathrm{~m}$, diameter: $0.25 \mathrm{~mm}$ and thickness of $0.25 \mu \mathrm{m}$ with the $\mathrm{CP}$ Sil stationary phase. $5 \mathrm{CB}$ with an oven temperature between $70^{\circ} \mathrm{C}$ up to $325^{\circ} \mathrm{C}$ with an increased rate of $10^{\circ} \mathrm{C} /$ min, a carrier gas of helium with a pressure of $16.30 \mathrm{kPa}$, a total rate of $40 \mathrm{~mL} / \mathrm{min}$ and a split ratio of 1:50.

\section{Antibacterial activity test by disc diffusion method}

Antibacterial activity test was carried out by the disc diffusion method using paper discs (about $6 \mathrm{~mm}$ in diameter) for $E$. coli and $S$. aureus bacteria. The antibacterial testing was carried out in three repetitions. The paper discs were immersed in samples with concentrations of $0.5 \%$, $1 \%, 1.5 \%$ and $2 \%$, then placed on culture medium (Mueller Hinton Agar) that has been inoculated with a suspension of the pathogen. Incubated at $37^{\circ} \mathrm{C}$ for $2 \times 24$ hours. 
Observations were made by measuring the inhibition zone diameter of inhibition zone based on the paper discs (Banjara et al. 2012; Chusri et al. 2011). The negative control used in this study is DMSO $10 \%(\mathrm{v} / \mathrm{v})$.

\section{Data analysis}

The presence of bioactive compound was analyzed by Gas Chromatography-Mass Spectroscopy (GC-MS) and antibacterial activity test was analyzed by quantitative method. The measurement of inhibition zone was determined by a caliper in each concentration.

\section{RESULTS AND DISCUSSION}

\section{Identification of active compounds}

Phytochemical test is a qualitative test of the content of the groups of secondary metabolites in a sample. Analysis of the chemical content of the leaves, flowers, and fruits of E. elatior was conducted at the Regional Health Laboratory, Jakarta by observing the presence or absence of precipitation reactions and color changes in the test tube. The analysis of phytochemical screening is presented in Table 2.

\section{Antibacterial activity test against $E$. coli}

The results of the antibacterial activity test of the ethanol extracts of E. elatior fruit on the growth of $E$. coli are presented in Table 3. Inhibition zones around disc paper were indicated antibacterial activity. The observation of the inhibition zone was carried out by diffusion agar method. The results of the antibacterial activity test on the three test extracts with concentrations of $0.5 \%, 1 \%, 1.5 \%$, and $2 \%$ on E. coli were shown in Figure 2.

\section{Antibacterial activity test against $S$. aureus}

The results of the antibacterial activity test of the ethanol extracts of E. elatior fruit on the growth of $S$. aureus were presented in Table 4. The results of the antibacterial activity test on the three test extracts with concentrations of $0.5 \%, 1 \%, 1.5 \%$ and $2 \%$ on $S$. aureus can be seen in Figure 3.

\section{GC-MS analysis}

The results of the GC-MS analysis of E. elatior leaf, flower and fruit extracts are presented in Table 5, Table 6 and Table 7.

\section{Discussion}

The results of phytochemical analysis showed that the leaves extract of $E$. elatior contained alkaloids, phenolic, flavonoids, saponins, tannins and steroids contents. The flowers extract of $E$. elatior contains alkaloids, phenolic, flavonoids, saponins, tannins and terpenoids. While the fruit extract of $E$. elatior contains alkaloids, phenolic, flavonoids, tannins and terpenoids (Table 2). These results following with (Effendi et al. 2019), where the results of phytochemical testing showed that the leaves powder of $E$. elatior contains alkaloid, flavonoid, saponin, steroid, tannin and phenolic. Kecombrang flower (E. elatior) contains flavonoid, saponin, tannin and terpenoid (Farida and Maruzy 2016). Meanwhile, the phytochemical compounds contained in the Kecombrang fruit (E. elatior), i.e., alkaloids, polyphenols, flavonoids, saponins and essential oils (Handayani 2010). Ahmad et al. (2015) also revealed that the total phenolic content for E. elatior fruit was $2.29 \mathrm{mg}$ GAE/g extract, while the total flavonoid content for E. elatior fruit was $1.78 \mathrm{mg} \mathrm{QE} / \mathrm{g}$ extract.

The presence of alkaloids, phenolic, flavonoids, saponins, tannins and terpenoids in this study indicated that extract of leaves, flowers and fruit of E. elatior has the potential as an antibacterial and antimicrobial. In line with Abdallah (2011) and Sadeek and Abdallah (2019), the bioactive compounds in E. elatior are known as potential sources for antibacterial agents. According to Juwita et al. (2018), the high potential antimicrobial activity possessed by E. elatior is due to the presence of phenolic, terpenoid and flavonoid contents.

Table 3. The results of antibacterial activity tests of the ethanol extracts of Etlingera elatior fruit against Escherichia coli

\begin{tabular}{ccc}
\hline $\begin{array}{c}\text { Concentrati } \\
\text { ons }(\%)\end{array}$ & $\begin{array}{c}\text { Average } \\
(\mathbf{m m})\end{array}$ & $\begin{array}{c}\text { Diameter zone of inhibition to } \\
\text { nearest } \mathbf{~ m m}\end{array}$ \\
\hline 0.5 & 0 & Weak \\
1 & 2.5 & Weak \\
1.5 & 7.8 & Intermediate \\
2 & 8.4 & Intermediate \\
\hline
\end{tabular}

Table 4. The results of antibacterial activity tests of the ethanol extracts of Etlingera elatior fruit against Staphylococcus aureus

\begin{tabular}{ccc}
\hline $\begin{array}{c}\text { Concentrations } \\
(\boldsymbol{\%})\end{array}$ & $\begin{array}{c}\text { Average } \\
(\mathbf{m m})\end{array}$ & $\begin{array}{c}\text { Diameter zone of inhibition } \\
\text { to nearest } \mathbf{~ m m}\end{array}$ \\
\hline 0.5 & 0 & Weak \\
1 & 0.7 & Weak \\
1.5 & 1.9 & Weak \\
2 & 2.4 & Weak \\
\hline
\end{tabular}

Table 2. Qualitative phytochemical analysis Etlingera elatior

\begin{tabular}{|c|c|c|c|c|c|c|c|c|c|}
\hline \multirow{2}{*}{$\begin{array}{l}\text { Phytochemical } \\
\text { screening (extract) }\end{array}$} & \multicolumn{3}{|c|}{ Alkaloids } & \multirow{2}{*}{ Phenolic } & \multirow{2}{*}{ Flavonoids } & \multirow{2}{*}{ Saponins } & \multirow{2}{*}{ Tannins } & \multirow{2}{*}{ Steroids } & \multirow{2}{*}{ Terpenoids } \\
\hline & Mayer & Dragendorff & Wagner & & & & & & \\
\hline E. elatior fruits & + & + & + & + & + & - & + & - & + \\
\hline E. elatior leaves & + & + & + & + & + & + & + & + & - \\
\hline E. elatior flowers & + & + & + & + & + & + & + & - & + \\
\hline
\end{tabular}


Table 5. The results of GC-MS analysis of leaves extract of Etlingera elatior

\begin{tabular}{ccccc}
\hline Peak & Retention time & Quality & Chemical components & Content (\%) \\
\hline 1 & 26.045 & 94 & Neophytadiene & 2,35 \\
2 & 27.258 & 47 & Hexadecanoic Acid, Methyl Ester & 1,48 \\
3 & 27.803 & 42 & Ethyl 4-methyl octanoate & 5,81 \\
4 & 28.307 & 99 & n-Hexadecanoic acid & 3,73 \\
5 & 28.541 & 89 & n-Hexadecanoic acid & 1,68 \\
6 & 28.706 & 70 & phytol & 4,05 \\
7 & 29.334 & 89 & 2-Aminoethanethiol Hydrogen Sulfate (Ester) & 3,71 \\
8 & 29.513 & 49 & Myrrhine & 2,11 \\
9 & 29.706 & 702 & Phenol, 2-(1-methyl-2-butenyl)-4-methoxy- & 1,86 \\
10 & 29.989 & 46 & Phenol, 2-(1-methyl-2-butenyl)-4-methoxy- & 3,04 \\
11 & 30.934 & 53 & Undeca-3,4-diene-2,10-dione,5,6,6-trimethyl- & 7,02 \\
12 & 31.134 & 58 & (+)-(9.Beta.H)-Labda-8 (17), 13 C-Diene-5-OL & 2,90 \\
13 & 31.458 & 90 & Z,E-3,13-Octadecadien-1-olacetate & 2,77 \\
14 & 31.733 & 99 & Squalene & 3,92 \\
15 & 32.002 & 58 & 1-Benzyl-4,6-Dimethoxy-2,3-Diphenylindole & 1,61 \\
16 & 32.120 & 48 & Cholesta-4,6-Dien-3-OL, 6-Fluoro-(3.Beta)- & 1,93 \\
17 & 32.451 & 46 & 1,3-Dithiolen, 2-(28-Norurs-12-EN-17-YL)- & 1,16 \\
\hline
\end{tabular}

Table 6. The results of GC-MS analysis of flower extract of Etlingera elatior

\begin{tabular}{|c|c|c|c|c|}
\hline Peak & Retention time & Quality & Chemical components & Content $(\%)$ \\
\hline 1 & 6.773 & 38 & Erythritol & 7,66 \\
\hline 2 & 10.875 & 93 & 2-Methoxy-4-Vinylphenol & 1,14 \\
\hline 3 & 15.302 & 95 & 1-Decene & 4,68 \\
\hline 4 & 19.232 & 81 & Tridecyl acetate & 3,09 \\
\hline 5 & 27.183 & 96 & Hexadecanoic Acid, Methyl Ester & 4,76 \\
\hline 6 & 27.989 & 38 & 8-Thiabicyclo [3,2,1]octan-3-ol-6-methoxy-, (3-endo, 6-exo)- & 9,39 \\
\hline 7 & 28.238 & 99 & n-Hexadecanoic acid & 5,15 \\
\hline 8 & 28.479 & 74 & Cis-13-Octadecenoic acid, emthyl ester & 9,30 \\
\hline 9 & 29.217 & 99 & 9,12 -Octadecadienoic acid & 5,79 \\
\hline 10 & 29.520 & 70 & 1,3;2,5-Dimethlene-4-methyl-d-rhamnitol & 3,31 \\
\hline 11 & 29.872 & 92 & 2-Dodecen-1-yl(-)succinic anhydride & 3,47 \\
\hline 12 & 30.292 & 60 & 2,15-Hexadecanedione & 2,28 \\
\hline 13 & 30.672 & 97 & 1-Docosane & 3,87 \\
\hline 14 & 30.982 & 44 & 10H-Phenothiazine & 3,54 \\
\hline 15 & 31.444 & 78 & 14-.Beta.-H-Pregna & 6,99 \\
\hline 16 & 31.865 & 78 & Methanone, (2-Aminophenyl) (2-Methoxyphenyl)- & 6,49 \\
\hline 17 & 32.265 & 56 & Hexadecanoic acid, 2-hydroxy-, methyl ester & 1,23 \\
\hline 18 & 32.499 & 96 & 1-Docosane & 4,57 \\
\hline 19 & 33.016 & 64 & Anthranilic Acid, N-Methyl-N-Phenyl- & 1,65 \\
\hline 20 & 33.568 & 47 & 1,3-Dioxolone, 2,2,4-trimethyl-5-tridecyl- & 2,40 \\
\hline 21 & 33.795 & 97 & (9Z)-9,17-Octadecadienal & 2,53 \\
\hline 22 & & & 3 (5)-(2hydrophenyl)-5(3)-Phenylpyrazole & 1.55 \\
\hline 23 & 49.013 & 56 & Tricosane & 1,70 \\
\hline
\end{tabular}

Table 7. The results of GC-MS analysis of fruit extract of Etlingera elatior

\begin{tabular}{|c|c|c|c|c|}
\hline Peak & Retention time & Quality & Chemical components & Content (\%) \\
\hline 1 & 5.538 & 27 & 1-Methyl-4-Methylenecyclohexane & 1,42 \\
\hline 2 & 6.428 & 72 & 6-Azabicyclo [3.2.1] octane & 3,98 \\
\hline 3 & 7.407 & 38 & 3-Ethoxy.Gamma.Butyrolactone & 6,14 \\
\hline 4 & 11.392 & 37 & 2-N-Propoxyamphetamine & 1,11 \\
\hline 5 & 12.785 & 27 & 1-Cyclopentene-1-1methanol, .Alpha.-Ethyl- & 3,77 \\
\hline 6 & 25.762 & 30 & (Tetrahydroxy Cyclopentadienone) Trcarbonyliron (0) & 2,51 \\
\hline 7 & 27.045 & 50 & (3Z)-3-Ethyl-2-Methyl-1,3-Hexadiene & 7,45 \\
\hline 8 & 27.189 & 97 & Hexadecanoic Acid, Methyl Ester & 5,09 \\
\hline 9 & 27.762 & 64 & Ethyl 3-Cyclohexylpropanoate & 5,01 \\
\hline 10 & 28.279 & 95 & n-Hexadecanoic acid & 10,01 \\
\hline 11 & 28.493 & 99 & 9-Octadecanoic acid (Z)-, methylester & 8,21 \\
\hline 12 & 28.865 & 55 & 2-Aminoethanethiol Hydrogen Sulfate (Ester) & 5,24 \\
\hline 13 & 29.244 & 98 & Oleic Acid & 16,31 \\
\hline 14 & 30.706 & 59 & Cis-11-Hexadecal & 4,86 \\
\hline 15 & 30.934 & 91 & Octadecenoate & 2,67 \\
\hline 16 & 31.451 & 95 & 14-.Beta. -H-Pregna & 5,09 \\
\hline
\end{tabular}




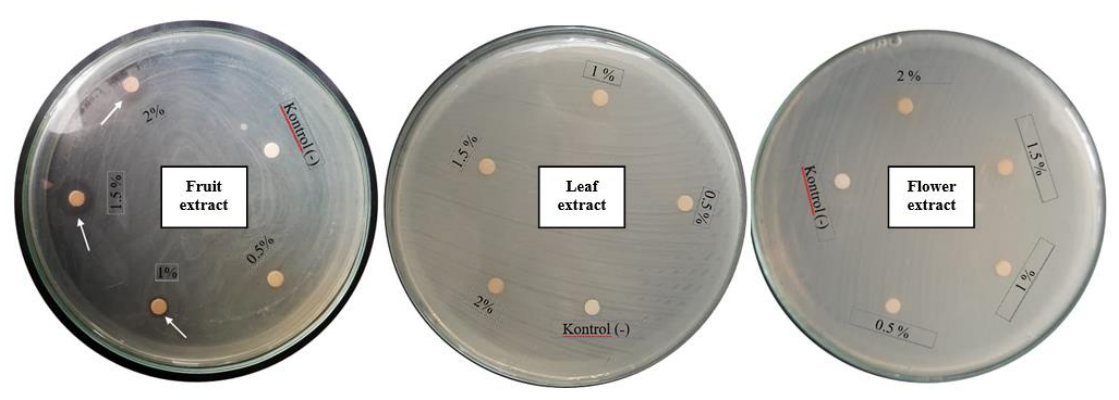

Figure 2. The diameter of the inhibition zone of Escherichia coli from the fruit, leaf and flower extract of Etlingera elatior with concentrations of $0.5 \%, 1 \%, 1.5 \%$ and $2 \%$.

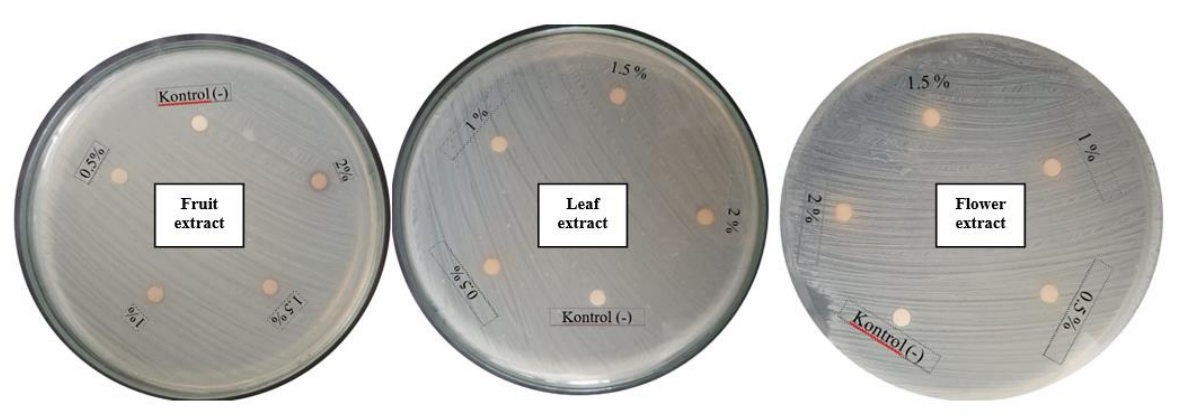

Figure 3. The diameter of the inhibition zone of Staphylococcus aureus from the fruit, leaf and flower extract of Etlingera elatior with concentrations of $0.5 \%, 1 \%, 1.5 \%$ and $2 \%$.

In this study, E. elatior was obtained at various of latitudes (Table 1). Where the latitude can affect the production of secondary metabolites in plants. These results following with Demasi et al. (2018), which stated that the distance of sea (latitude) had an influence on both morphological and phytochemical traits. The contents of active substances in a plant were influenced by their environment (Liu et al. 2016). The presence or absence of certain secondary metabolites in medicinal plants are influenced by a variety of factors such as light, climate, temperature, groundwater, soil fertility and salinity (Giweli et al. 2013). The concentrations of phenolic compounds in plant were influenced by temperature, soil composition, ultraviolet radiation and rainfall (Kouki and Manetas 2002; Monteiro et al. 2006). The tannin's content can be influenced by environmental changes and development of the plant (Hatano et al. 1986; Salminen et al. 2001).

The data in Table 3 showed that the fruit extract of $E$. elatior has antibacterial properties to inhibit the growth of E. coli with an average zone of inhibition size of 8.4 $\mathrm{mm} / 2 \%, 7.8 \mathrm{~mm} / 1.5 \%$ and $2.5 \mathrm{~mm} / 1 \%$. The fruit extracts of $E$. elatior are seen by the diameter of inhibition formed around the paper discs (Figure 3). However, the best extracts of E. elatior fruit to inhibit the growth of E. coli was at a concentration of $2 \%(8.4 \mathrm{~mm})$. Those values translated to categories of intermediate. A higher concentration of ethanol extract, which may will produce a larger zone of inhibition. According to Morales et al. (2003), the activity of the antimicrobial inhibition zone was grouped into four categories, i.e., weak activity $(<5 \mathrm{~mm})$, intermediate $(5-10 \mathrm{~mm})$, strong $(>10-20 \mathrm{~mm})$ and very strong (>20-30 mm). Previous study revealed that the Kecombrang fruit peel formula has antimicrobial activity to inhibit the growth of $E$. coli bacteria with ranges from 24,103-26,877 mm (Naufalin 2013).

The data in Table 4 showed that the fruit extract of $E$. elatior also has antibacterial properties to inhibit the growth of $S$. aureus with an average zone of inhibition size of $2.4 \mathrm{~mm} / 2 \%, 1.9 \mathrm{~mm} / 1.5 \%$ and $0.7 \mathrm{~mm} / 1 \%$. However, those values translated to categories of weak. In line with Pan et al. (2009), the inhibition zone of 0-3 mm includes the weak category, $3-6 \mathrm{~mm}$ good, and $\geq 6 \mathrm{~mm}$ strong. Simangunsong (2019) reported that the fruit extract of $E$. elatior has antibacterial activity to inhibit the growth of $S$. aureus at a concentration of $500 \mathrm{mg} / \mathrm{mL}$ with the diameter of clear zone of $22.06 \mathrm{~mm}$. Meanwhile, the negative control used in this study is DMSO 10\% (v/v). DMSO is a surfactant that can dissolve polar and nonpolar materials. It also showed no antibacterial activity in Figure 3 and Figure 4 (Brito et al. 2017).

The difference in diameter of inhibition zones at each concentration possibly was due to differences in the magnitude of active substances contained in the extract. In addition, the diameter of the inhibition zone was also influenced by the level of sensitivity of the bacteria. E. coli had higher antibacterial activity than $S$. aureus. This is related to the differences in the constituent components of the cell structure. Gram-positive bacteria contain 90\% peptidoglycan and a thin layer of negatively charged teichoic acid and teichuronic acid. In Gram-negative bacteria, there is an outer layer of the cell wall that contains $5-20 \%$ peptidoglycan. This layer is the second lipid layer 
called the lipopolysaccharide layer. This layer is composed of phospholipids, polysaccharides, and proteins (Madigan et al. 2000).

The result of GC-MS analysis of leaves extract of $E$. elatior in Table 5, it showed that the main components of the extract are undeca-3,4-diene-2,10-dione,5,6,6trimethyl-with content of $7,02 \%$ and ethyl 4-methyl octanoate with content of $5,81 \%$. The main components of the extract of E. elatior flower are 8-Thiabicyclo [3,2,1]octan-3-ol-6-methoxy-, (3-endo, 6-exo)- with content of $9,39 \%$ and cis-13-Octadecenoic acid, methyl ester with content of $9,30 \%$ (Table 6). In addition, the main components of the extract of E. elatior fruit are oleic acid with content of $16,31 \%$ and n-Hexadecanoic acid with content of $10,01 \%$. GCMS is a method of separating organic compounds using gas chromatography (GC) and mass spectrometry (MS). The principle of separation is based on differences in the volatile ability of the compound and based on interactions with the stationary phase (capillaries).

\section{ACKNOWLEDGEMENTS}

The authors would like to thank WRI (World Resources Institute). Our special thanks to all staff members in the Laboratory of Microbiology, Department of Biology, Faculty of Mathematics and Natural Sciences, Syiah Kuala University, Banda Aceh, Indonesia. This research was funded by the Indonesian Ministry of Research, Technology and Higher Education (Directorate of Research and Community Service-DRPM 2021, grant number 025/LL13/LT/AKA/2021-090/LPPM-USM/VII/2021).

This research was supported by the Ministry of Research and Technology/National Research and Innovation Agency of the Republic of Indonesia (Kemristek-Brin) 2021 University Cooperation Research (PKPT) scheme.

\section{REFERENCES}

Abdallah EM. 2011. Plants: an alternative source for antimicrobials. J Appl Pharm Sci 6: 16-20.

Ahmad AR, Juwita, Ratulangi SAD, Malik A. 2015. Analysis levels of polyphenols and flavonoids of fruit and leaf methanol extract of patikala Etlingera elatior (Jack) R.M.SM). J Pharm Sci Res 2 (1): 110. DOI: $10.7454 /$ psr.v2i1.3481

Banjara RA, Jadhav SK, Bhoite SA. 2012. Antibacterial activity of di-2ethylaniline phosphate screened by paper disc diffusion method. J Appl Pharm Sci 2 (7): 230- 3. DOI: 10.7324/JAPS.2012.2720

Bettelheim KA. 2000. The role of nonO157 VTEC. J Appl Microbiol Symp Supp 88: 38S-50S. DOI: 10.1111/j.1365-2672.2000.tb05331.x

Brito R, Silva G, Farias T, Ferreira P, Ferreira S. 2017. Standardization of the safety level of the use of DMSO in viability assays in bacterial cells.

Bush LM, Vazquez-Pertejo MT. 2021. Staphylococcal Infections. MSD Manuals Professional Version.

Chusri S, Chaicoch N, Thongza-ard W, Limsuwan S, Voravuthikunchai SP. 2012. In vitro antibacterial activity of ethanol extracts of nine herbal formulas and its plant components used for skin infections in Southern Thailand. J Med Plants Res 6 (44): 5616-5623.

Dabbaghi A, Kabiri K, Ramazani A, Zohuriaan-Mehr MJ, Jahandideh A. 2009. Synthesis of bio-based internal and external cross-linkers based on tannic acid for preparation of antibacterial superabsorbents. Polym Adv Technol 30: 2894-2905. DOI: 10.1002/pat.4722
Demasi S, Caser M, Lonati M, Cioni PL, Pistelli L, Najar B, Scariot V. 2018. Latitude and altitude influence secondary metabolite production in peripheral alpine populations of the Mediterranean species Lavandula angustifolia Mill. Front Plant Sci 9: 983. DOI: 10.3389/fpls.2018.00983

Effendi KN, Fauziah N, Wicaksono R, Erminawati, Arsil P, Naufalin R. 2019. Analysis of bioactive components and phytochemical of powders stem and leaves of kecombrang (Etlingera elatior). IOP Conf Ser: Earth Environ Sci 406 (2019): 012003. DOI: 10.1088/17551315/406/1/012003

Elfahmi, Woerdenbag H, Kayser O. 2014. Jamu: Indonesian traditional herbal medicine towards rational phytopharmacological use. J Herbal Med 4 (2): 51-73. DOI: 10.1016/j.hermed.2014.01.002

Farida S, Maruzy A. 2016. Torch Ginger: A review of its traditional uses, phytochemistry and pharmacology. J Indones Med Plant 9 (1): 19-28.

Fatima N, Nayeem N. 2016. Toxic Effects as a Result of Herbal Medicine Intake. Toxicology-New Aspects to This Scientific Conundrum. InTech Open, London, UK. DOI: 10.5772/64468

Ghasemzadeh A, Jaafar, Hawa ZE, Rahmat A, Ashkani S. 2015. Secondary metabolites constituents and antioxidant, anticancer and antibacterial activities of Etlingera elatior (Jack) R. M. Sm. grown in different locations of Malaysia. BMC Complement Altern Med 15 (1): 8-9. DOI: 10.1186/s12906-015-0838-6

Giweli AA, Džamić AM, Soković M, Ristić M, Janaćković P, Marin PD. 2013. The chemical composition, antimicrobial and antioxidant activities of the essential oil of Salvia fruticosa growing wild in Libya. Arch Biol Sci 1 (65): 321-329. DOI: 10.2298/ABS1301321G

Habsah M, Ali AM, Lajis NH, Sukari MA, Yap YH, Kikuzaki H, Nakatani N. 2005. Antitumour-promoting and cytotoxic constituents of Etlingera elatior. Malays J Med Sci 12 (1): 6-12.

Handayani V, Ahmad AR, Sudir. 2010. Antioxidant activity test of patikala flower and leaf methanol extract (Etlingera elatior (Jack) R.M.Sm) using DPPH Method. Pharm Sci Res 1 (2): 86-93. DOI: 10.7454/psr.v1i2.3321

Hatano T, Kira R, Yoshizaki M, Okuda T. 1986. Seasonal changes in the tannins of Liquidambar formosana reflecting their biogenesis. Phytochemistry 25: 2787-2789. DOI: 10.1016/S00319422(00)83742-5

Jackie T, Haleagrahara N, Chakravarthi S. 2011. Antioxidant effects of Etlingera elatior flower extract against lead acetate induced perturbations in free radical scavenging enzymes and lipid peroxidation in rats. BMC Res Notes 4 (1): 67. DOI: 10.1186/17560500-4-67

Jawetz E, Melnick JL, Adelberg EA. 2005. Medical Microbiology. Salemba Medika, Jakarta. [Indonesian]

Jawetz, Melnick, Adelberg. 2008. Medical Microbiology. EGC, Jakarta. [Indonesian]

Juwita T, Puspitasari IM, Levita J. 2018. Review article: torch ginger (Etlingera elatior): a review on its botanical aspects, phytoconstituents and pharmacological activities. Pak J Biol Sci 21 (4): 151-165. DOI: $10.3923 / p j b s .2018 .151 .165$

Kouki M, Manetas Y. 2002. Resource availability affects differentially the levels of gallotannins and condensed tannins in Ceratonia siliqua. Biochem Syst Ecol 30: 631-639. DOI: 10.1016/S03051978(01)00142-9

Lachumy SJT, Sasidharan S, Sumathy V, Zuraini Z. 2010. Pharmacological activity, phytochemical analysis and toxicity of methanol extract of Etlingera elatior (torch ginger) flowers. Asian Pac J Trop Med 3 (10): 769-774. DOI: 10.1016/S19957645(10)60185-X

Liu W, Yin D, Li N, Hou X, Wang D, Li D, Liu J. 2016. Influence of environmental factors on the active substance production and antioxidant activity in Potentilla fruticosa L. and its quality assessment. Sci Rep 6: 28591. DOI: 10.1038/srep28591

Madduluri S, Rao KB, Sitaram B. 2013. In vitro evaluation of antibacterial activity of five indigenous plants extract against five bacterial pathogens of human. Int J Pharm Pharm Sci 5 (4): 679-684.

Madigan MT, Martinko JM, Parker J. 2000. Brock Biology of Microorganisms, 9th Edition. Prentice-Hall Inc., New Jersey.

Mahboubi A, Asgarpanah J, Sadaghiyani PN, Faizi M. 2015. Total phenolic and flavonoid content and antibacterial activity of Punica granatum L. var. pleniflora flowers (Golnar) against bacterial strains causing foodborne diseases. BMC Complement Altern Med 15: 366. DOI: $10.1186 / \mathrm{s} 12906-015-0887-\mathrm{x}$ 
Maimulyanti A, Prihadi AR. 2015. Chemical composition, phytochemical and antioxidant activity from extract of Etlingera elatior flower from Indonesia. J Pharmacogn Phytochem 3: 233-238.

Manoi, F. 2009. Binahong (Anredera cordifolia) (Ten) Steenis as a medicine. Jurnal Warta Penelitian dan Pengembangan Tanaman Industri 15 (1): 3. [Indonesian]

Mert-Türk F. 2006. Saponin versus plant fungal pathogens. J Cell Mol Biol 5: 13-17.

Monteiro JM, Albuquerque UP, Lins Neto EMF, Araújo EL, Albuquerque MM, Amorim ELC. 2006. The effects of seasonal climate changes in the Caatinga on tannin level. Rev Bras Farmacogn 16: 338-344. DOI: 10.1590/S0102-695X2006000300010

Morales G, Sierra P, Mancilla, Parades A, Loyola LA, Gallardo O, Borquez J. 2003. Secondary metabolites from four medicinal plants from Northern Chile, antimicrobial activity, and biotoxicity against Artemia salina. J Chile Chem 48: 2. DOI: 10.4067/S0717 97072003000200002

Naufalin R. 2013. Antimicrobial activity of fruit peel kecombrang formula (Nicolaia speciosa Horan) as natural preservative. In: Jember; Proceeding of National Seminary PATPI, 26-29 August 2013 [Indonesian]

Ningtyas R. 2019. Antioxidant and antibacterial of kecombrang leaf extract (Etlingera elatior (Jack) R.M. Smith) as natural preservative against Escherichia coli and Staphylococcus aureus. [Thesis]. Syarif Hidayatullah State Islamic University, Jakarta. [Indonesian]

Nor Asiah MN, Afifah A, Liza N, Hidayah AB, Nizam WA. 2019. Aqueous extract of Etlingera elatior flowers improved blood glucose control, kidney function and histology of streptozotocin-induced diabetic rat. J Sustain Sci Manag 14 (3): 80-91.

Nuria, Maulita C, Faizaitun, Arvin, Sumantri. 2009. Antibacterial activity test of ethanol extract of Jatropha leaves (Jatropha curcas L) against Staphylococcus Aureus Atcc 25923, Escherichia coli Atcc 25922 and Salmonella typhi Atcc 1408. Mediagro 5 (2): 26-37. DOI: 10.31942/md.v5i2.559

Oktavia GAE, Kuswantoro F, Wardhani PK. 2019. Traditional utilization of ginger torch (Etlingera elatior (Jack) R.M.Sm.) in Bedugul, Bali and its conservation in Bali Botanic Garden. In: Indonesia, AIP Conference Proceedings, Indonesia, 03 July 2019. DOI: 10.1063/1.5115621 [Indonesian]

Pan X, Chan F, Wu T, Tang H, Zhao Z. 2009. The acid, bile tolerance and antimicrobial property of Lactobacillus acidophilus NIT. J Food Control 20: 598-602. DOI: 10.1016/j.foodcont.2008.08.019

Poulsen. 2012. Book Review: Etlingera of Sulawesi. Gard Bull (Singap) 64 (2): 529-531.

Sabilu Y, Sahidin, Mukaddin A, Bittikaka Y, Tawa RA, Paddo J. 2017 The utilization of sikala (Etlingera elatior) as traditional medicine in Porehu District, North Kolaka Regency, Southeast Sulawesi Province, Indonesia. Adv Environ Biol 11 (9): 5-9
Sadeek AM, Abdallah EM. 2019. Phytochemical compounds as antibacterial agents: a mini-review. Saudi Arabia Glob J Pharm Sci 7 (4): 131-136. DOI: 10.19080/GJPPS.2019.07.555720

Salminen JP, Ossipov V, Haukioja E, Pihlaja K. 2001. Seasonal variation in the content of hydrolyzable tannins in leaves of Betula pubescens. Phytochemistry 57:15-22. DOI: DOI: 10.1016/s0031-9422(00)005021

Saudah, Fitmawati, Roslim DI, Zumaidar, Darusman, Ernilasari. 2021. Ethnobotany Etlingera elatior (Jack) R.M. smith cikala in Ethnic Gayo. In: Bengkulu, Proceedings of the 3rd KOBI Congress, International and National Conferences (KOBICINC 2020). Konsorsium Biologi Indonesia (KOBI) and University of Bengkulu, Bengkulu, 24-25 November. DOI: 10.2991/absr.k.210621.034 [Indonesian]

Schroeder L. 2011. Global Biodiversity. East Africa, ENVS 220, Map.

Silalahi M. 2016. Etlingera elatior (Jack) R. M. Smith: Benefits of biological activity. In: Proceeding of National Seminary of Biology Education. Yogyakarta State University, Yogyakarta, 26 November 2016. [Indonesian]

Simangunsong CN. 2019. Antibacterial activity test of kecombrang fruit extract (Etlingera elatior (Jack) R.M. Smith) in mouthwash. [Thesis]. University of Northern Sumatra, Medan. [Indonesian]

Sofowora A, Ogunbodede E, Onayade A. 2013. The role and place of medicinal plants in the strategies for disease prevention. Afr J Tradit Complement Altern Med 10 (5): 210-229. DOI: 10.4314/ajtcam.v10i5.2

Srey C, Sontimuang C, Thengyai S, Ovatlarnporn C, Puttarak P. 2014. Research article activities of Etlingera elatior rhizome. J Chem Pharm Res 6 (12): 885-891.

Sukandar D, Radiastuti N, Jayanegara I, Ningtiyas R. 2011. Characterization of antibacterial compounds of aqueous extracts of kecombrang leaf (Etlingera elatior). Valensi 2 (3): 414-419. DOI: 10.15408/jkv.v2i3.112

Sukandar D. 2010. Characterization of antibacterial active compounds from the aqueous extract of kecombrang flower (Etlingera elatior) as functional food ingredients. Valensi 333-339. DOI: $10.15408 /$ jkv.v2i1.232

World Health Organization. 2004. WHO guidelines on developing consumer information on proper use of traditional, complementary and alternative medicine. WHO Library Cataloguing-in-Publication Data.

Zan CH, Rahmat A, Akim M, Banu MAN, Othman F, Lian GC. 2011. Anti-proliferative effects of pandan leaves (Pandanus amarylfolius), kantan flower (Etlingera elatior) and turmeric leaves (Curcuma

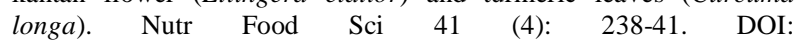
10.1108/00346651111151366 